\title{
Determinants of Rulindo tea farmers' perception towards organic farming: a MASS::stepAIC() approach
}

\section{Shakiru Muhamadi ${ }^{*}$ (D) Ismet Boz $^{1}$ (1D}

${ }^{1}$ Department of Agricultural Economics, Ondokuz Mayis University, 55139, Samsun, Turkey. E-mail: dadushakir@gmail.com."Corresponding author.

ABSTRACT: The current study determined the factors influencing the perception of tea farmers towards organic tea production in Rulindo District, Rwanda. This study used both qualitative and quantitative data from face to face interviews and questionnaires completed with 156 tea farmers and other key informants in the tea sector who were randomly selected in 2019. Using function step AIC in R's MASS package, the final multiple logistic regression model showed that generating income from tea production, participation in Umuganda, conveying messages at Ihangari, participation to agricultural shows, and receiving training from Farmers Field Schools (FFS) influenced farmers' perceptions towards organic tea production. Thus, the results of this study could be useful to stakeholders in Rwanda's tea sector, such as policymakers and decision-makers. They can act as a source of information when developing a more sustainable research-based tea extension program. Moreover, the results of this study can be used during the capacity building of farmers about organic tea production.

Key words: organic tea farming, farmer field schools, Umuganda, Rulindo, RWANDA.

Determinates da percepção dos cafeicultores de Rulindo em relação à agricultural orgânica: uma abordagem MASS::stepAIC

RESUMO: O objetivo deste estudo é determinar os fatores que influenciam a percepção dos produtores de chá em relação à produção de chá orgânico no distrito de Rulindo, Ruanda. Esta pesquisa utilizou dados qualitativos e quantitativos de entrevistas e questionários presenciais preenchidos com 156 cafeicultores e outros informantes-chave do setor de chá que foram alocados aleatoriamente em 2019. Usando a etapa de função AIC no pacote MASS de R, o modelo final de regressão logística múltipla mostrou que a participação em Umuganda, transmitindo mensagens na ihangari, discussões com um revendedor Agro nas aldeias, obtendo renda com as vendas de folhas de chá verde fresco, acesso dos cafeicultores à Internet, participação na exposição agrícola e treinamento em escolas agrícolas da Cooperativa Os cafeicultores tiveram à previsão da percepção da produção orgânica de chá. Assim, os resultados deste estudo podem ser úteis para as partes interessadas no setor de chá de Ruanda, como formuladores de políticas e tomadores de decisão. Eles podem atuar como fonte de informação ao desenvolver um programa de extensão do chá mais sustentável, baseado em pesquisa. Além disso, os resultados deste estudo podem ser utilizados durante a capacitação dos agricultores sobre o cultivo de chá orgânico.

Palavras-chave: cultivo orgânico de chá, escolas de campo para agricultores, Umuganda, Rulindo, RWANDA.

\section{INTRODUCTION}

Agriculture has been a back born of any developing country (CINEMRE \& KILIÇ, 2015), like Rwanda for provoking economic growth. Rwanda's agriculture sector employed approximately 75.3 percent of the labor force, generated approximately 63 percent of the country's export revenues and provided approximately $30.9 \%$ of the country's GPD (INDEXMUNDI, 2019), which has had a massive pie on the national budget than the mother industry agriculture of (MINECOFIN, 2018). Coffee and tea are among the main foreign exchange earner for the country (INDEXMUNDI, 2019). Not only Rwanda's tea sector has earned about 64.3 million USD foreign exchange compared to 64.1 Million USD of coffee (MINECOFIN,2018) but has also employed 60\% of the workforce for the country (INDEXMUNDI, 2019). Among the 20 tea cooperatives in this country (National Agricultural Export Development Board,2019), Rulindo's ASSOPTHE cooperative that supplies $70 \%$ of SORWATHE tea factory (NAEB, 2019) has more than 3000 tea farmers with $70 \%$ women and $30 \%$ men among other economic and 
social benefits of Rwanda's tea sector (NAEB,2019). This shows how strategic is Rwanda's tea sector for the country that is building on already impressive success stories to achieve sustainable development goals (SDG) and its recently launched vision of 2050. Now, with such social and economic developmental roles the tea sector has continuously played, Rwanda's Agricultural Ministry in partnership with a private tea processing and exporting company-SORWATHE launched a massive campaign for organic tea farming whose fresh green tea leaves harvests are fetching higher premiums than non-organic tea. The campaigns used different indigenous platforms such as "inteko y'abaturage" and "Umuganda" among others. This campaign aimed to increase the rate of adoption of organic tea production practices in Rwanda's Rulindo District. For this adoption to be successful and become sustainable, the farmers should know how beneficial is this technology (TATLIDIL et al., 2009; VAN THANH et al., 2015) to own it. A decision to own new technology depends on the perception the farmers attach to the technology to influence the adoption rate (SARKER \& ITOHARA 2018). Earlier research has shown that the perception of farmers on technology is influenced by socioeconomic characteristics such as land ownership and (TATLIDIL et al., 2009; PATIDAR \& PATIDAR, 2015; SAKTHI, 2017) and information-seeking behaviors like Participating in workshop-farming events (TATLIDIL et al., 2009) and that this perception changes from one farmer to another (BAGHERI, 2010; VAN THANH et al., 2015). It is of great importance to explore the specific factors that influence the perception of tea farmers in Rwanda's Rulindo district, in the end, would help the concerned institution in designing a kind of customized extension system (TATLIDIL et al., 2009) for increased adoption of organic tea farming practices.

Earlier studies conducted on the determinants of perception of farmers showed a positive relationship between socioeconomic status and the perceived importance of sustainable agriculture (BOZ, 2016; TATLIDIL et al., 2009), and organic farming has been proved to be performing well in various domains of sustainability like decreased usage of pesticides (RÖÖS et al., 2018). FAHAD et al., (2018) study showed that the level of education and location were among the factors that affected farmers' perception. STEFANOVIĆ (2015) used a binary logistic regression model, which results showed that age and education level of respondents were among the significant predictors of perception. For adopting organic tea production practices to be increased from the current levels, and a research-based tea extension program to be developed, the perception of tea farmers regarding organic tea production is of great importance (MOTTALEB, 2018). In the end, it will help to develop a more sustainable way of organic tea production. Although, many studies have been conducted on farmers' perception around the world, Rwanda lacks this type of research as only several studies have been done on this issue (NABAHUNGU \& VISSER,2013; MC GUINNESS \& TAYLOR, 2014). This study was the first attempt to determine farmers' perceptions of organic tea farming in the northern district of Rwanda. In the determination of the study purpose and objectives, earlier research of ANDERSON et al., (2005), TEKIN et al., (2016), YU et al., (2017), REGASSA et al., (2019), DÍAZPÉREZ et al., (2019), and NUÑEZ, (2020) were explicitly used.

The overall purpose of this study was to determine the factors that influenced Rulindo's farmers' perception of organic farming. The specific objectives included the following:

(1) To determine the socio-economic characteristics of tea farmers.

(2) To measure farmers' perception regarding organic tea farming

(3) To determine the factors that influence the perception of tea farmers towards organic farming

(4) To develop recommendations that will increase the adoption of organic tea farming in the region and contribute towards the achievement of sustainable development goals (SDG's)

\section{MATERIALS AND METHODS}

\section{Study area}

The data collection was carried in the Rulindo district because of its closeness to Rwanda's capital Kigali, a market niche with a higher tea purchasing power relative to the country's other Districts. Figure 1 shows the location of Rulindo in the Northern Province of Rwanda. This district has a tropical type of climate, characterized by successions in rainy and drought seasons. It also has an annual average precipitation and temperature of $1,243.3 \mathrm{~mm}$, and $19{ }^{\circ} \mathrm{C}$, respectively. These conditions offer a favorable climate for farming. Rulindo's hydrograph, climate, and topography make this district endowed with cash crop acreage. In 2015 Rulindo had 7619 hectares of agricultural land devoted to vegetable production, 2302.47 hectares to coffee production, and 52 hectares to Stevia (Stevia rebaudiana Bertoni) production. Also, many other cash crops can economically be grown in 


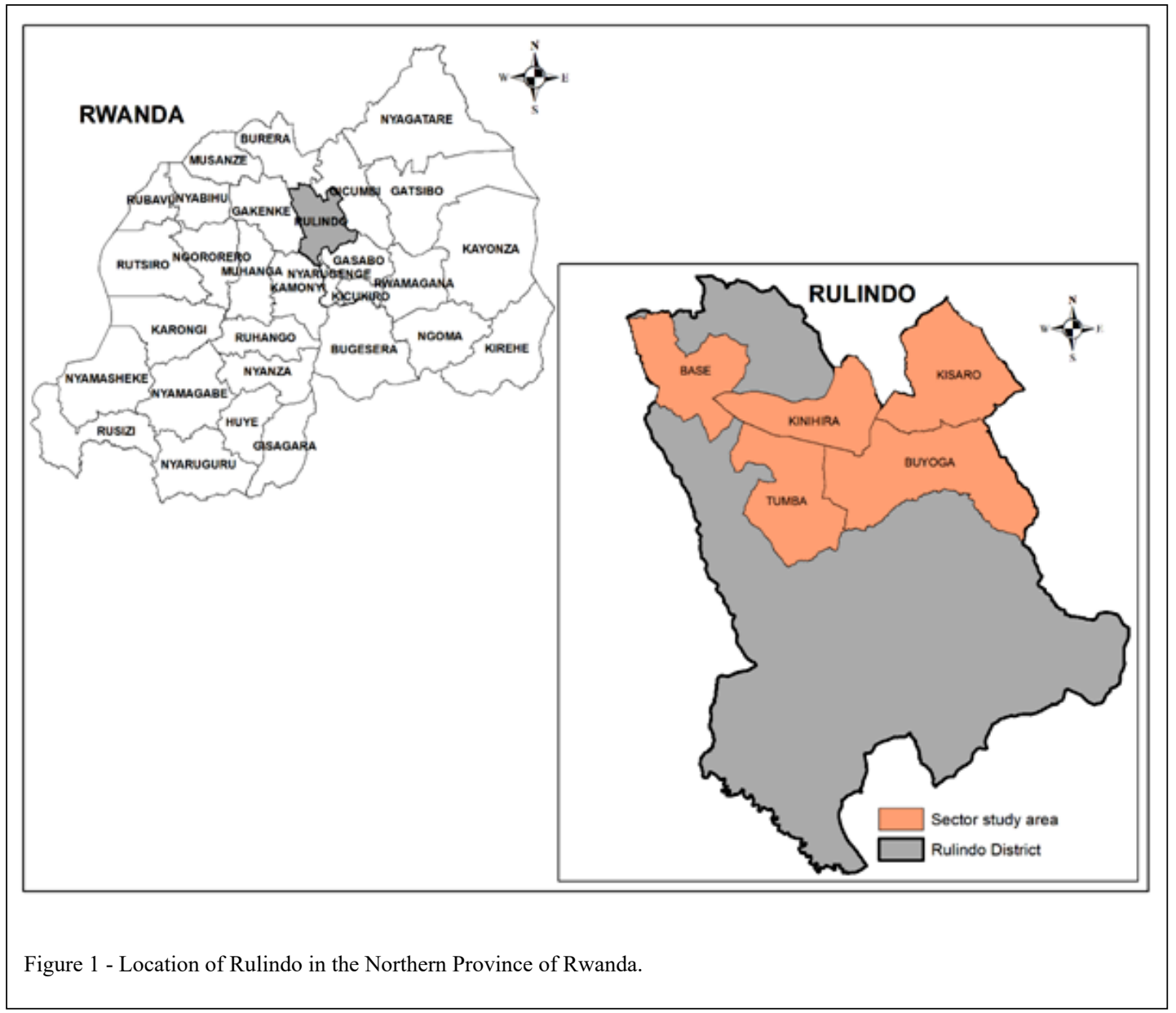

the district (RULINDO DISTRICT, 2013). Rulindo district has two tea cooperatives, one of them is nonorganic tea farmers' cooperative (ASOPTHE) and the other one is organic farmers' cooperative (HOT). By the time this study was being done, a total of 1023.191 ha of tea plantations were operating under the ASOPTHE cooperation (ASSOCIATION OF RWANDA TEA GROWERS, 2020). Alternatively, the number of tea plantations under the HOT cooperative was 125 ha. (HILLSIDE ORGANIC TEA FARMERS' COOPERATIVE, 2019).

\section{Sampling and data collection}

To draw an accurate sample size to represent the tea farmers' population in the district, this study used DANIEL's methods (1999) and DANIEL et al., (2018). This method of sample size determination was previously used by other researchers (NAING et al., 2006; MUNENE AND KASAMANI, 2018). Using a 95\% confidence level, $7.69 \%$ margin of error $(\varepsilon)$, and $60 \%$ proportion of respondents $(\dot{\mathrm{P}})$, the minimum sample size was calculated as 156 . This was proportionally distributed among the villages and respondents were selected randomly from each tea collection center around Kinihira and the nearby villages. The sample consisted of persons with different levels of training especially key informants who had a thorough understanding of the sociocultural and economic aspects of the study area and finally all members that cultivating tea were separately interviewed.

The data collection instrument of this study included questions related to socioeconomic characteristics of farmers, farm-level practices, and a section focused on exploring the extent of tea farmers' agreement with the statements related to the selected indicators of organic farming. Data were collected in July, August, and September 2019. Since farmers met at different tea collection centers (Ihangare in the local language) on different tea-plucking days, 
most of the questionnaires were completed at these centers. Because tea farmers were waiting for several hours at the Ihangare for their tea to be weighed and loaded on FUSO trucks for transportation to the SORWATHE factory (Rwanda's oldest private tea company), they had time to participate in this survey. Their agronomist and sometimes an assistant of the agronomist (Monagri in the local language) guided them to respond to the questionnaires. The remaining questionnaires were completed by visiting the farmers on their tea plots and meeting them in their homes and in the fields. Those who were unreachable were replaced with others within the same village or tea collection center. Data were collected on different variables such as age in years, farm size in hectares, education status by the number of years spent in school, farming experience by the number of years involved in farming, and gender as being male or female.

\section{Model specification for determinants of the farmers perception of organic farming}

To implement a binary logistic regression model first organic farming perception index was developed to create a dichotomous nature of our dependent variable. To develop this index, 46 selected organic farming statements that cover the four aspects (Ecology, health, fairness, and care) of organic farming stated by IFOAM (IFOAM, 2019; RUNDGREN \& PARROTT, 2006) were asked on a 5-point Likert scale with $1=$ No importance, $2=$ Low importance, $3=$ Moderate importance, $4=$ High importance, and $5=$ Very high importance. Therefore, if a respondent assigned the maximum rating of 5 to every practice, he or she was assumed to have the highest perception of organic farming 230 (46x5); and conversely, if a respondent assigned the minimum rating of 1 to every practice, he or she was assumed to have the lowest perception of organic farming 46 (46x1). Using the 'describe()' of Hmisc package of R language programming (R CORE TEAM, 2020), the mean score of organic tea perception for all 156 tea farmers was calculated and $162.7482(\mathrm{SD}=22.66951)$ Considering this mean, with the help of 'ifelse ()' function, an index category of the selected organic farming statements that cover the four $t$ aspects of organic farming was dichotomized with 0 or values $(\leq 162.7482)$ as having low levels of perception of organic tea farming and one or values $(\geq 162.7482)$ were considered the higher level of perception of organic tea farming. Therefore, the dependent variable took the values of zero (0) and one (1) Using Hmisc::describe (dichotomous variable) showed that 66.7 percent $(n=56)$ had a lower perception and 33.3 percent $(n=50)$ had a higher perception of organic tea farming. The explanatory variables were selected from social-economic characteristics and the informationseeking behavior of the responding farmers.

$$
(y=1)=\frac{e^{x \beta}}{1+e^{x \beta}}=f(x \beta)
$$

Where prob $(y=1)$ is the probability of one. $e$ Is the base of the natural logarithm.

$f(x \beta)$ Is the standard logistic distribution function.

$x$ Is the explanatory variable involving the selected independent variable.

The odds ratios for all independent variables were calculated considering the following formula:

$\operatorname{Exp} \beta$ or odds $=\frac{\mathrm{P}}{1-\mathrm{P}}$

Results were transformed into odds ratios (OR), which is always an indicator of the change in the odds of an event occurring resulting from a unit change of the predictor (NORTON et al., 2018). It can be interpreted that holding other variables constant, for a single independent variable how many times of the likelihood of the respondents with a high level of organic farming perception category increase when the related explanatory variable is increased by one unite. This method of data analysis was used similarly by several researchers (SPRINCE et al., 2003; OHLMACHER \& DAVIS, 2003; JASINSKI et al., 2005; RAUTIAINEN et al., 2009; MCDONALD, 2009).

With 15 candidate variables in table 1 for the multivariate logistic regression model, there are various selecting variable approaches like stepwise that combine both forward selection and backward elimination to be removed or added the predictor candidates for the model solely on statistical backgrounds without compromising the model prediction accuracy (MCCULLAGH, 2019; SHI et al., 2018; HOSMER \& LEMESHOW, 2000). In this study, we used R's MASS::stepwiseAIC() which was developed by VENABLES \& RIPLEY (2013) to automatically select a better subset of independent variables for our predictive modeling that had the lowest AIC at the same time decreasing the overfitting effect (GARCÍA et al., 2009; BARNES et al., 2008; ÇELIK \& SENGER (2014), BUSKIRK \& KOLENIKOV, 2015; ZHANG, 2016; MOORE et al., 2016; ABDULQADER, 2017). The final model was reached that had a higher significance level by excluding the $2^{\text {nd }}$ and $11^{\text {th }}$ observations, which did not go well with the model.

\section{RESULTS AND DISCUSSION}

\section{Sociodemographic characteristics}

Socioeconomic characteristics included in this study were age, marital status, farm size, 
cooperative membership, the time spent on tea plot, livestock ownership, educational level, home-plot distance, and income from tea production. In addition frequencies of participation in Farmers Field School training, participating in Umuganda, conveying messages at Ihangari, using the Internet, participation in agricultural shows, and meeting with agri-dealers. These variables were used were selected to describe tea farmers' sociodemographic characteristics as well as to have a possible influence on farmers' perception towards organic tea production. Therefore, they were properly coded and made the explanatory variables of the stepwise logistic regression model (table 1).

Results of the study showed that the mean age of Rulindo districts' tea farmers who participated in this study was 49 , and most of them were married. They operated an average of 0.66 hectares of agricultural land. All farmers are members of tea producers' cooperatives operating in the region. They spent an average of $3.68 \mathrm{hrs}$ per day on tea plots to perform various farming activities from maintaining the orchards to harvesting the tea leaves. The average distance from home to tea plot is 0.85 kilometers indicating that the tea plots are not too far from farmers' houses. Since tea is one of the prominent cash crops in the district a large majority of farmers (78\%) own income from tea production.
These results indicated that an increased market value of tea production in the district will make significant contributions to the incomes and well-being of the farmers residing in the district.

Farmers Field School, Umuganda, and Ihangari are critical regional organizations that provide training to farmers, exchange information on agricultural and rural issues and enable farmers to come together in social terms. Farmers' participation in the events of these organizations is extremely important, and it was assumed that the more farmers occur in these events the better they deal with farming and other rural issues. Results showed that farmers spent approximately several hours a month for participation in the training of Farmers Field School, one hour a day in Umuganda, and one hour a week for conveying messages at Ihangary. Although, farmers' participation levels to these three events were not too bad, frequency of using the Internet (approximately one hour a month), participation in agricultural shows (Rarely), and meeting with agridealers (approximately one hour a month) was low.

\section{Determinants of tea farmers perception}

The R's output shows the estimation of the stepwise regression, along with the coefficients, their respective standard errors, Wald z-statistic,

Table 1 - Descriptive statistics of both response and predictor variables in the multiple logistic reg model.

\begin{tabular}{|c|c|c|c|}
\hline Variables & Description of the variables & Mean & S. D \\
\hline Dependent variable & $(1=$ higher perception, $0=$ otherwise $)$ & 0.33 & 0.46 \\
\hline \multicolumn{4}{|c|}{ 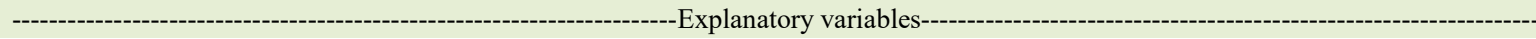 } \\
\hline Age of farmer & Continuous variable (year) & 48.88 & 14.16 \\
\hline Marital status & $1=$ Single, 2 = Married, 3 = Divorced, 4 = Widow & Median (2) & 0.9 \\
\hline Farm size & Continuous variable (hectare) & 0.66 & 1.74 \\
\hline Cooperative Membership & $1=$ Member, $0=$ otherwise & 1 & 0 \\
\hline Time spent on tea plot & Continuous variable (Hours a day) & 3.68 & 2.78 \\
\hline Livestock ownership & $1=$ owned, $0=$ otherwise & 1 & 0.51 \\
\hline Education level & $\begin{array}{c}5=\text { Master's degree, } 4=\text { College degree, } 3=\text { High } \\
\text { school, } 2=\text { Primary school, } 0=\text { Illiterate }\end{array}$ & 2.28 & 4.35 \\
\hline Home-plot distance & Continuous variable $(\mathrm{Km})$. & 0.85 & 3.88 \\
\hline Income from tea & $1=$ Yes, $0=$ otherwise & 1.78 & 0.45 \\
\hline Frequency of participating in FFS trainings & Measured on a 7 point Likert scale ${ }^{*}$ & 3.03 & 2.35 \\
\hline Frequency of participating in Umuganda & Measured on a 7 point Likert scale ${ }^{*}$ & 6.25 & 2.13 \\
\hline Frequency of conveying messages at Ihangari & Measured on a 7 point Likert scale ${ }^{*}$ & 3.93 & 1.98 \\
\hline Frequency of using the Internet & Measured on a 7 point Likert scale ${ }^{*}$ & 2.39 & 3.31 \\
\hline Frequency of participation in agricultural shows & Measured on a 7 point Likert scale ${ }^{*}$ & 1.27 & 1.25 \\
\hline Frequency of meeting with Agrodealers & Measured on a 7 point Likert scale ${ }^{*}$ & 2 & 2.72 \\
\hline
\end{tabular}

*7=Rarely, $6=$ Approximately one hour a month, $5=$ Several hours a month, $4=$ Approximately one hour a week, $3=$ Several hours a week, 2 = Approximately one hour a day, 1 = Several hours a day. 
the corresponding p-values, and significance levels. Looking at how well did predictor variables predict the response variable the researcher used the "PseudoR2" function of BaylorEdPsych package to get both the Nagelkerke and Cox.Snell focusing on the predictive power of various R2 measures. The initial model had 0.364 and 0.485 of Cox.Snell and Nagelkerke values, while the final model had 0.573 and 0.719 Cox.Snell and Nagelkerke values, respectively. Considering the results of Nagelkerke test, it can be said that the predictor variables in the final multivariate model explained $71.9 \%$ of the changes in the response variable/perception of tea farmers towards organic tea farming. As far as the model's fitness evaluation is concerned, before stepwise regression, the AIC value was 235.641 and after which it became 212.65 and thus, the final model was considered since it had the smallest AIC value (AKAIKE, 1974). With the variance inflation factor of less than 10 , which was obtained from the 'vif()' function, the researcher concluded that no explanatory variable caused multicollinearity issues.

The significant variables in the final model were income from selling tea (TeaSosInc), frequency of participation to Umuganda (Umuganda), frequency of conveying messages at Ihangari (Ihangari4), frequency of participation to agricultural shows (Agrisho6), and frequency of participation to Farmers' Field School training (CooperatFFS6). These were associated with the perception of farmers towards organic tea farming.

From the table 2 results, it can be seen that keeping other variables constant, an increase in the income generated from tea production by one 1 Rwandan francs, would increase the likelihood of having a higher perception of organic tea farming by 0.292 times and its significant $p$-value indicates that it is significant in determining the perception. The second significant variable was participation in Umuganda, which had an increasing perception

Table 2 - Multiple logistic regression estimates of factors that determine the perception of organic tea farmers in Rulindo District.

\begin{tabular}{|c|c|c|c|c|c|c|}
\hline Name of the variable & Codes entered & Odds-Ratio & Estimate(B) & Std. Error & $Z$ value & $\begin{array}{l}\operatorname{Pr} \\
(>|Z|)\end{array}$ \\
\hline Income from selling tea & TeaSosInc & 0.2922926 & $-1.230 \mathrm{e}+00$ & $5.262 \mathrm{e}-01$ & -2.338 & $0.0194^{* *}$ \\
\hline \multirow{7}{*}{ Frequency of using the Internet } & interne1 & 0.5199618 & $-6.540 e-01$ & $1.542 \mathrm{e}+00$ & -0.424 & 0.6714 \\
\hline & Interne2 & $3.128 \mathrm{e}-08$ & $-1.728 \mathrm{e}+01$ & $2.783 \mathrm{e}+03$ & -0.006 & 0.9950 \\
\hline & Interne3 & 0.4186664 & $1.755 \mathrm{e}+01$ & $2.194 \mathrm{e}+03$ & 0.008 & 0.9936 \\
\hline & Interne4 & 0.7426726 & $-2.975 e-01$ & $1.847 \mathrm{e}+00$ & -0.161 & 0.8720 \\
\hline & Interne5 & $3.708 \mathrm{e}-08$ & $-1.711 \mathrm{e}+01$ & $3.956 \mathrm{e}+03$ & -0.004 & 0.9965 \\
\hline & Interne6 & $3.987 \mathrm{e}-09$ & $-1.934 \mathrm{e}+01$ & $2.640 \mathrm{e}+03$ & -0.007 & 0.9942 \\
\hline & Interne7 & 1.443398 & $3.670 \mathrm{e}-01$ & $1.052 \mathrm{e}+00$ & 0.349 & 0.7273 \\
\hline Frequency of participation to Umuganda & Umuganda & 16.81044 & $2.822 \mathrm{e}+00$ & $1.563 \mathrm{e}+00$ & 1.806 & $0.0710^{*}$ \\
\hline \multirow{5}{*}{$\begin{array}{l}\text { Frequency of conveying messages at } \\
\text { Ihangari }\end{array}$} & Ihangari3 & 1.475062 & $3.887 \mathrm{e}-01$ & $9.430 \mathrm{e}-01$ & 0.412 & 0.6802 \\
\hline & Ihangari4 & 80.15803 & $4.384 \mathrm{e}+00$ & $2.069 \mathrm{e}+00$ & 2.119 & $0.0341^{* *}$ \\
\hline & Ihangari5 & 3.043475 & $1.113 \mathrm{e}+00$ & $9.682 \mathrm{e}-01$ & 1.149 & 0.2504 \\
\hline & Ihangari6 & 1.340711 & $2.932 \mathrm{e}-01$ & $1.002 \mathrm{e}+00$ & 0.293 & 0.7698 \\
\hline & Ihangari7 & 8.482456 & $2.138 \mathrm{e}+00$ & $1.779 \mathrm{e}+00$ & 1.201 & 0.2296 \\
\hline $\begin{array}{l}\text { Frequency of participation to agricultural } \\
\text { shows }\end{array}$ & Agrisho6 & 148.7103 & $5.002 \mathrm{e}+00$ & $2.305 \mathrm{e}+00$ & 2.170 & $0.0300^{* *}$ \\
\hline \multirow{3}{*}{ Frequency of listening to radio } & Radio3 & $1.688 \mathrm{e}-17$ & $-3.862 \mathrm{e}+01$ & $5.595 \mathrm{e}+03$ & -0.007 & 0.9945 \\
\hline & Radio6 & 1.000000 & $2.754 \mathrm{e}-11$ & $5.595 \mathrm{e}+03$ & 0.000 & 1.0000 \\
\hline & Radio7 & 1.55131 & $4.391 \mathrm{e}-01$ & $5.698 \mathrm{e}-01$ & 0.771 & 0.4409 \\
\hline \multirow{3}{*}{ Frequency of participating to FFS trainings } & $\begin{array}{l}\text { CooperatFFS } \\
5\end{array}$ & 0.2636149 & $1.939 \mathrm{e}+01$ & $3.956 \mathrm{e}+03$ & 0.005 & 0.9961 \\
\hline & $\begin{array}{l}\text { CooperatFFS } \\
6\end{array}$ & 0.0834923 & $-2.483 e+00$ & $1.801 \mathrm{e}+00$ & -1.379 & 0.1679 \\
\hline & $\begin{array}{c}\text { CooperatFFS } \\
7\end{array}$ & 0.1610565 & $-1.826 \mathrm{e}+00$ & $9.185 \mathrm{e}-01$ & -1.988 & $0.0468^{* *}$ \\
\hline
\end{tabular}

Significant at "**, 0.05 , and "*, 0.1 level. 
towards organic tea farming. A 16.810 odds value indicates that moving upper-level participation among the 7-point Likert scale increases farmers' belonged to the high perception group by almost 17 times. A study conducted in the same region reported similar results (MUHAMADI \& BOZ, 2016). The third significant variable influencing farmers' perceptions towards organic tea production was conveying messages at Ihangari (Ihangari4- representing the frequency of spending approximately one hour a week). The significant odds value indicates that moving to the frequency level of several hours a week holding all other variables constant, increase the likelihood of having a higher perception of organic tea farming by 80.158 . The fourth significant variable of the model was the frequency of participating in agricultural shows (Agrisho6) with the frequency of participating for one hour a month. The odds ratio associated with this variable indicates that the likelihood of having a higher perception towards organic tea farming is increased by 148.710 times as farmers move to an upper level of participation in agricultural shows. Finally, the fifth significant variable influencing Rulindo farmers' perceptions towards organic farming was participation in Farmers Field SchoolinCooperatFFS7) training. FFS training increases farmers' attitudes and behavior, which makes them innovators and role model farmers. Therefore, these are useful activities particularly giving training to increase the knowledge of organic tea farming. Results showed that the least frequency level (Rarely) of participation to FFS training had a negative sign, indicating that the less farmers participate in these trainings the lower the perception they have towards organic tea farming. The odds ratio indicated that moving from "Rarely' frequency level to "one hour a month" frequency level would increase the likelihood of having a higher perception towards organic tea farming by 0.161 times, holding all other variables constant.

\section{CONCLUSION}

For Rulindo district authorities to use its tea climate favorable conditions used to further reduce poverty among residents that mainly depend on agriculture, with NAEB's need to increase national tea export volumes and SORWATHE's urge to increase its production volumes among others, the three signed MOU (Memorandum of Understanding) in 2017 that would see more organic tea farming hectares increase. If organic tea farming is to be highly adopted in Rulindo, it is; therefore, necessary to know the factors that could drive the perception of tea farmers. This research indicated that Rulindo districts' tea farmers that participated in this study were all married with a mean age of 49 years, had a primary level of education with 2.28-mean of years spent at school, a mean farm size of 0.66 ha, all were members to the tea cooperatives, on average they spent $3.68 \mathrm{~h}$ on the tea plots and traveled an average 0.85 kilometers from their residentials to the tea plots. The face-to-face interview with tea farmers results showed that getting income from fresh green tea leaves sales, participation in Umuganda, messages conveying at Ihangari, participating in agricultural shows, and participation in Cooperative's FFS training proved to be significantly associated with predicting the perception of organic tea farming. Thus, the results of this study can be used for policy implementations. This is the first study conducted in the research area to measure farmers' perception of organic tea farming. Its results are useful to stakeholders in Rwanda's tea sector such as policymakers and decision-makers, as it can act as a source of information concerning drivers of organic tea perception. Thus, it is recommended that scientific communication points that would help to further scale up the adoption of organic tea farming be done when farmers in Umuganda, at tea collection centers/ihangari, Agricultural show, and during the tea cooperatives' Farmer Field School training. Additionally, we commend this study's output is used during the capacity building of farmers about organic tea farming. Finally, it is worth saying that this research focused on the perception of tea farmers on organic tea farming but did not predict whether these farmers would adopt organic farming practices. Thus, it is of great importance to conduct a study on the likelihood of the farmers to adopt organic tea farming practices.

\section{ACKNOWLEDGMENTS}

Mr. SHAKIRU Muhamadi received a Ph.D. Scholarship from Turkish Government awarded to international students and researchers. The authors greatly appreciate the administrative support for this research from the Rwanda's Ministry of Agriculture and animal resources-NAEB, SORWATHE and ASSOPTHE.

\section{BIOETHICS AND BIOSECURITY COMMITTEE APPROVAL}

We authors of the article entitled " Determinants of Rulindo tea farmers' perception towards organic farming: a MASS::stepAIC() approach" declared, for all due purposes, the project that increased the present data of the same has not been submitted for evaluation to the Ethics Committee of Ondokuz Mayis University, but we are aware of the contents of Resolution No. 466, of December 12, 
2012, of the Brazilian National Health Council "http://conselho. saude.gov.br/resolucoes/2012/Reso466.pdf" if it involves human.

Thus, the authors assume full responsibility for the presented data and are available for possible questions, should they be required by the competent authorities.

\section{DECLARATION OF CONFLICT OF INTERESTS}

The authors declare no conflict of interest. The founding sponsors had no role in the design of the study; in the collection, analysis, or interpretation of data; in the writing of the manuscript, and in the decision to publish the results.

\section{AUTHORS' CONTRIBUTIONS}

Ismet Boz is the supervisor of this research. The rest of the research has been done by Mr. SHAKIRU Muhamadi and is the corresponding author.

\section{REFERENCES}

ABDULQADER, Q. M. Applying the binary logistic regression analysis on the medical data. Science Journal of University of Zakho, v.5, n.4, p.330-334, 2017. Available from: <https://sjuoz. uoz.edu.krd/index.php/sjuoz/article/view/442>. Accessed: Oct. 12, 2019. doi: $10.25271 / 2017.5 .4 .388$.

AKAIKE, H. Anew look at the statistical model identification. IEEE transactions on automatic control, v.19, n.6, p.716-723, 1974. Available from: <https://ieeexplore.ieee.org/document/1100705>. Accessed: Aug. 12, 2019. doi: 10.1109/TAC.1974.1100705.

ANDERSON, et al. Determinants of farmer adoption of organic production methods in the fresh-market produce sector in California: A logistic regression analysis. n.1846-2016 p.152504, 2005. Available from: <https://ideas.repec.org/p/ags/ waeasa/36319.html>. Accessed: Aug. 20, 2019. doi: 10.22004/ ag.econ.36319.

Association of Rwanda Tea Growers. ASOPTHEdata. [Data file]. Rulindo: Association of Rwanda Tea Growers, 2020. Accessed: Aug. 25, 2019.

BAGHERI, A. Potato farmers' perceptions of sustainable agriculture: the case of Ardabil province of Iran. Procedia-Social and Behavioral Sciences, v.5, p.1977-1981, 2010. Available from: $\quad<$ https://www.sciencedirect.com/science/article/pii/ S1877042810017738>. Accessed: Jul. 12, 2020. doi: 10.1016/j. sbspro.2010.07.399.

BARNES, M. et al. A model to predict outcomes for endovascular aneurysm repair using preoperative variables. European Journal of Vascular and Endovascular Surgery, v.35, n.5, p.571-579, 2008. Available from: <https://www.sciencedirect.com/science/ article/pii/S1078588407007526>. Accessed: Oct. 12, 2019. doi: 10.1016/j.ejvs.2007.12.003

BOZ, I. (2016). Effects of environmentally friendly agricultural land protection programs: Evidence from the Lake Seyfe area of Turkey. Journal of Integrative Agriculture, v.15, n.8, p.19031914, 2016. Available from: <https://daneshyari.com/article/ preview/10179940.pdf>. Accessed: Feb. 30, 2019. doi: 10.1016/ S2095-3119(15)61271-0.
BOZ, I., SHAHBAZ, P. Land tenure in tea farming and exploring factors influencing a rural household's decision to exit or enter farming. Ciência Rural, v.50, n.12, 2020. Available from: <https://www.scielo.br/scielo.php?pid=S010384782020001200901\&script $=$ sci arttext $>$. Accessed: Nov. 13, 2019. doi: $10.1590 / 0103-8478$ cr20200014.

BUSKIRK, T. D, ; KOLENIKOV, S. Finding respondents in the forest: A comparison of logistic regression and random forest models for response propensity weighting and stratification. Survey Methods: Insights from the Field, p.1-17, 2015. Available from: $<$ https://surveyinsights.org/?p=5108>. Accessed: Mar. 13, 2019. doi: 10.13094/SMIF-2015-00003.

ÇELIK, A. K., \& SENGER, Ö. Risk factors affecting fatal versus non-fatal road traffic accidents: the case of Kars province, Turkey. International Journal for Traffic and Transport Engineering, v.4, n.3, p.339-351, 2014. Available from: <https:// trid.trb.org/view/1326064>. Accessed: Apr. 13, 2020. doi: 10.7708/ ijtte.2014.4(3).07.

CINEMRE, H. A.; KILIC, O. Tarım ekonomisi. Ondokuz Mayıs Üniversitesi, Ziraat Fakültesi, Bask1, Samsun, 2015. Ders Kitabı No:11, 5. Available from: <https://avys.omu.edu.tr/storage/app/ public/okilic/68817/1.\%20Hafta.pdf>. Accessed: Apr. 13, 2020

DANIEL W. W. Biostatistics: A Foundation for Analysis in the Health Sciences. 7th edition. New York: John Wiley \& Sons, 1999. Available from: <https://onlinelibrary.wiley.com/doi/ abs/10.1002/bimj.4710370610>. Accessed: Apr. 15, 2020. doi: 10.1002/bimj.4710370610.

DE JANVRY, A., SADOULET, E., \& SURI, T. Field experiments in developing country agriculture. In Handbook of Economic Field Experiments: North-Holland, 2017. Vol.2, p.427-466. Available from: $\quad<$ https://www.sciencedirect.com/handbook/handbook-ofeconomic-field-experiments/vol/2/suppl/C > Accessed: Apr. 15, 2020. doi: 10.1016/bs.hefe.2016.08.002.

DÍAZ-PÉREZ, M, et al. Application of Logistic Regression Models for the Marketability of Cucumber Cultivars. Agronomy, v.9, n.1, p.17, 2019. Available from: <https://www.mdpi.com/2073-4395/9/1/17>. Accessed: Apr. 15, 2020. doi: 10.3390/agronomy9010017.

DR. K. R, SAKTHI DEVI, "A study on Attitude of Farmers towards Organic Farming", International Journal of Current Research and Modern Education, v.2, n.1, p.159-162, 2017. Available from: <https://zenodo.org/record/806881>. Accessed: Apr. 16, 2020. doi: 10.5281/zenodo.806881.

ERBAUGH, J. M, et al. Assessing the impact of farmer field school participation on IPM adoption in Uganda. Journal of International Agricultural and Extension Education, v.17, n.3, p.5-17, 2010. Available from: <https://www.cabdirect.org/ cabdirect/abstract/20113229533>. Accessed: Apr. 17, 2020. doi: $10.5191 /$ jiaee. 2010.17301

FAHAD, S, et al. Evaluation of farmers' attitude and perception towards production risk: Lessons from Khyber Pakhtunkhwa Province, Pakistan. Human and Ecological Risk Assessment: An International Journal, v.24, n.6, p.1710-1722, 2018. Available from: $<$ https://www. cabdirect.org/cabdirect/abstract/20113229533>. Accessed: May, 17, 2020. doi: 10.5191/jiaee.2010.17301.

FRANK E HARRELL Jr, with contributions from Charles Dupont and many others. Hmisc: Harrell Miscellaneous. R package

Ciência Rural, v.51, n.6, 2021. 
version 4.4-1. https://CRAN.R-project.org/package=Hmisc, 2020. Available from: < https://cran.r-project.org/web/packages/Hmisc/ Hmisc.pdf $>$. Accessed: Dec. 25, 2019.

GAITAN S. B, : RÍOS M. D. Socio-economic and technological typology of avocado cv. Hass farms from Antioquia (Colombia). Ciência Rural, v.50, n.7, 2020. Available from: <https:// www.scielo.br/scielo.php? script $=$ sci_arttext\&pid $=$ S0 103 84782020000700202\&tlng=en>. Accessed: Dec. 25, 2012. doi: 10.1590/0103-8478cr20190188.

HILLSIDE ORGANIC TEA FARMERS' COOPERATIVE. HOTData. [Data file]. Rulindo: Hillside organic tea farmers' cooperative, 2019. Available from: <https://www.teaimporters. com/sorwathe/>. Accessed: Aug. 25, 2019.

HOSMER D. W, ; LEMESHOW S. Applied Logistic Regression 2nd Edition Wiley. New York. 2000. Available from: <https:// onlinelibrary.wiley.com/doi/book/10.1002/0471722146>. Accessed: Sep. 25, 2019. doi: 10.1002/0471722146.

IFOAM. "The IFOAM Norms for Organic Production and Processing, Version 2005.", 2005. Available from: <https:// www.ifoam.bio/our-work/how/standards-certification/organicguarantee-system/ifoam-standard $>$. Accessed: Jan. 25, 2019

INDEXMUNDI. Rwanda Economy Profile 2019, 2019. Available from: <https://www.indexmundi.com/rwanda/economy profile html>. Accessed: Sep. 25, 2019.

JASINSKI, E, et al. Physical landscape correlates of the expansion of mechanized agriculture in Mato Grosso, Brazil. Earth Interactions, v.9, n.16, p.1-18, 2005. Available from: <https://journals.ametsoc. org/view/journals/eint/9/16/ei143.1.xml?tab_body=fulltext-display>. Accessed: Jan. 21, 2019. doi: 10.1175/EI143.1.

MC GUINNESS, S., \& TAYLOR, D. Farmers' perceptions and actions to decrease crop raiding by forest-dwelling primates around a Rwandan forest fragment. Human Dimensions of Wildlife, v. 19, n.2, p.179-190, 2014. Available from: <https://www.tandfonline. com/doi/full/10.1080/10871209.2014.853330>. Accessed: Jan. 21, 2019. doi: $10.1080 / 10871209.2014 .853330$.

MCCULLAGH, P. (2019). Generalized linear models. Routledge. Available from: <https://www.taylorfrancis. com/books/generalized-linear-models-mccullaghnelder/10.1201/9780203753736>. Accessed: Jan. 21, 2019. doi: $10.1201 / 9780203753736$

McDONALD, J. H. Handbook of biological statistics. Baltimore, MD: sparky house publishing, 2009. v.2, p.6-59. Available from: $<$ http://www.biostathandbook.com/>. Accessed: Jan. 22, 2019.

MINECOFIN. (April, 2018). Budget Framework Paper 2018/2019-2020/2021. Kigali, Rwanda: MINECOFIN. Available from: $\quad<$ http://www.minecofin.gov.rw/fileadmin/templates/ documents/Budget Management and Reporting Unit/Budget Framework_Papers/2018-2021_Budget_Framework_Paper.pdf $>$. Accessed: Feb. 16, 2019.

MOORE, H, et al. Familiarity with and uptake of alternative methods to control sheep gastro-intestinal parasites on farms in England. Veterinary parasitology, v.221, p.1-8, 2016. Available from: $\quad<$ https://www.sciencedirect.com/science/article/abs/pii/ S0304401716300577>. Accessed: Sep. 16, 2019. doi: 10.1016/j. vetpar.2016.03.002.
MOTTALEB, K. A. Perception and adoption of a new agricultural technology: evidence from a developing country. Technology in society, v.55, p.126-135, 2018. Available from: <https://www. sciencedirect.com/science/article/pii/S0160791X18300769>. Accessed: Oct. 16, 2019. doi: 10.1016/j.techsoc.2018.07.007.

MUHAMADI, S., \& BOZ, I. Farmers' perceptions and determinants of sustainable agriculture at the farm level: a case study of Musanze, Kirehe and Gisagara districts of Rwanda. 2016. (Master's Degree in Agricultural Economics). Ondokuz Mayis University. Available from: <http://acikerisim.omu.edu.tr/xmlui/ handle/20.500.12712/23228>. Accessed: Oct. 16, 2019.

Munene, N. K.; Kasamani, B. S. A Mobile-based Tea Farming Information System. International Journal of Computer Applications, v.975, p.8887, 2018. Available from: $\quad<$ https://www.ijcaonline.org/archives/volume179/ number19/28979-2018916334>. Accessed: Oct. 18, 2019. doi: $10.5120 /$ ijca2018916334.

NABAHUNGU, N. L, ; VISSER, S. M. FARMERS'KNOWLEDGE AND PERCEPTION OF AGRICULTURAL WETLAND MANAGEMENT IN RWANDA. Land Degradation \& Development, v.24 n.4, p.363-374, 2013. Available from: $<$ https:// onlinelibrary.wiley.com/doi/abs/10.1002/ldr.1133>. Accessed: Dec. 18, 2019. doi: 10.1002/1dr.1133.

NAING, et al. Practical issues in calculating the sample size for prevalence studies. Archives of orofacial Sciences, v.1, p.9-14, 2006. Available from: <https://www.academia.edu/23980977/ Practical Issues in Calculating the Sample Size for Prevalence_Studies $>$. Accessed: Jul. 18, 2019.

National Agricultural Export Board. (2019). Introduction to the tea sector in Rwanda. kigali Rwanda. NAEB. Available from: $<$ https://naeb.gov.rw/index.php?id=44>. Accessed: Aug. 27, 2019.

NORTON, E. C, et al. Odds ratios-current best practice and use. Jama, v.320, n.1, p.84-85, 2018. Available from: <https:// jamanetwork.com/journals/jama/article-abstract/2686777>. Accessed: Jul. 19, 2019. doi: 10.1001/jama.2018.6971.

NUÑEZ. Job preferences and expectations for students of accounting and administration: gender differences. REFCalE: Electronic Magazine Training and Educational Quality. ISSN 1390-9010, v.7, n.3, p.107-118, 2020. Available from: <https:// refcale.uleam.edu.ec/index.php/refcale/article/view/3075>. Accessed: Oct. 18, 2020. doi: 10.1016/S1138-4891(09).

OHLMACHER, G. C; DAVIS, J. C. Using multiple logistic regression and GIS technology to predict landslide hazard in northeast Kansas, USA. Engineering geology, v.69, n.3-4, p.331-343, 2003. Available from: <https://pubs.er.usgs.gov/publication/70025384>. Accessed: Oct. 18, 2020. doi: 10.1016/S0013-7952(03)00069-3.

PATIDAR, S; PATIDAR, H, A study of perception of farmers towards organic farming. International Journal of Application or Innovation in Engineering \& Management, v.4(3), p.269-277, 2015. Available from: <https://www.ijaiem.org/Volume4Issue3/ IJAIEM-2015-03-31-91.pdf>. Accessed: Oct. 1, 2020.

R CORE TEAM. R: A language and environment for statistical computing. R Foundation for Statistical Computing, Vienna, Austria. URL https://www.R-project.org/, 2020. Available from: $<$ http://cran.univ-paris1.fr/web/packages/dplR/vignettes/introdplR.pdf>. Accessed: Oct. 1, 2020. 
RAUTIAINEN et al. Risk factors for serious injury in Finnish agriculture. American journal of industrial medicine, v. 52 n. 5 , p.419-428, 2009. Available from: <https://onlinelibrary.wiley. com/doi/abs/10.1002/ajim.20688>. Accessed: Sep. 11, 2020. doi: 10.1002/ajim.20688.

REGASSA, et al. Preference in the use of full childhood immunizations in Ethiopia: the role of maternal health services. Patient preference and adherence, v.13, p.9199, 2019. Available from: <https://search.proquest.com/ openview/5d30b008a4b4e86a71af8fbd66cac56a/1.pdf?pqorigsite $=$ gscholar \&cbl $=3933306>$. Accessed: Jul. 11, 2020. doi: 10.2147/PPA.S189844

REHMAN, A. et al. Effect of agricultural growth on poverty reduction, its importance and suggestions. Transylvanian Review, Vol.24, No. 05, 2019. Available from: <https://www.semanticscholar.org/paper/ Effect-of-Agricultural-Growth-on-Poverty-Reduction\%2C-RehmanJing-dong/a 9c252fd063e26de348b2857fc031873c942ddf0>. Accessed: Jan. 11, 2020

RÖÖS, et al. Risks and opportunities of increasing yields in organic farming. A review. Agronomy for sustainable development, v.38, n.2, p.14. (2018). Available from: <https://link.springer.com/ article/10.1007/s13593-018-0489-3>. Accessed: Jan. 11, 2020. doi: $10.1007 / \mathrm{s} 13593-018-0489-3$

RUNDGREN, G, Organic agriculture and food security: IFOAM 2006. Available from: <http://www.grolink.se/Resources/ studies/117_Dossier_1_OA_and_Foodsecurity-1.pdf $>$. Accessed: Jan. 11, 2020 .

SARKER, M,: ITOHARA, Y. Factors influencing the extent of practice of organic farming technologies: a case study of Tangail district in Bangladesh. American Journal of Agricultural and Biological Sciences, v.3(3), p.584-590, 2008. Available from: $\quad<$ https://www.semanticscholar.org/paper/FactorsInfluencing-the-Extent-of-Practice-of-A-of-Sarker-Itohara/ cc9923e91ad54dac4dddcafa8acc836ab763d0cb>. Accessed: Sep. 11, 2020. doi: 10.3844/AJABSSP.2008.584.590.

SHI., et al. Variable selection and validation in multivariate modelling. Bioinformatics, v.35, n.6, p.972-980, 2018. Available from: $<$ https://academic.oup.com/bioinformatics/ article/35/6/972/5085367>. Accessed: Sep. 02, 2020. doi: 10.1093/ bioinformatics/bty 710
SPRINCE, N. L, et al. Risk factors for agricultural injury: A casecontrol analysis of Iowa farmers in the Agricultural Health Study. Journal of agricultural safety and health, v.9 n.1, p.5. 2003 Available from: <https://pubmed.ncbi.nlm.nih.gov/12673912/>. Accessed: Oct. 02, 2020. doi: 10.13031/2013.12346.

STEFANOVIĆ, J. Smallholder Farming Systems in Kenya: Climate Change Perception, Adaptation and Determinants. 2015. (Master's Degree in Sustainable Development Excellence in Sustainability, MSD), Universität Basel. Available from: $<$ https:// www.syngentafoundation.org/sites/g/files/zhg576/f/masterthesis juliastefanovic_final.pdf $>$. Accessed: Oct. 03, 2020.

TATLIDIL, F. et al. Farmers' perception of sustainable agriculture and its determinants: a case study in Kahramanmaras province of Turkey. Environment, Development and Sustainability, v.11(6), p.1091-1106, 2009. Available from: <https://ideas.repec.org/a/spr/ endesu/v11y2009i6p1091-1106.html>. Accessed: Jun. 15, 2020. doi: $10.1007 / \mathrm{s} 10668-008-9168-\mathrm{x}$.

VAN THANH, N. et al. Farmers' Sustainable Agriculture Perception in the Vietnam Uplands: the Case of Banana Farmers in Quang Tri Province. Research Journal of Applied Sciences, Engineering and Technology, v.10(8), p.960-967, 2015. Available from: <https://www.semanticscholar.org/paper/Farmers\%5C'Sustainable-Agriculture-Perception-in-the-Th\%C3\%A0nhSukprasert/b31d842b73e4cb5c9b2eb31c651ee240091db6fe>. Accessed: Sep. 15, 2020. doi:10.19026/RJASET.10.2453.

VENABLES W. N, RIPLEY B. D. Modern applied statistics with S-PLUS. Springer Science \& Business Media; 2013. Available from: < https://link.springer.com/book/10.1007/978-1-4757-27197>. Accessed: Oct. 15, 2019. doi: 10.1007/978-1-4757-3121-7.

YU, Y, et al. Wrapper feature selection based multiple logistic regression model for determinants analysis of residential electricity consumption. 2017 Asian Conference on Energy, Power and Transportation Electrification (ACEPT), Singapore, v.24, n.5, p.1-8, 2017. Available from: <https://ieeexplore.ieee. org/document/8168587>. Accessed: Jul. 15, 2019. doi: 10.1109/ ACEPT.2017.8168587.

ZHANG, Z. Variable selection with stepwise and best subset approaches. Annals of translational medicine, v.4, n.7, 2016 Available from: <http://atm.amegroups.com/article/view/9706/ html>. Accessed: Sep. 10, 2019. doi: 10.21037/atm.2016.03.35. 